\title{
Environment and agriculture of the transitional period from the Late Bronze to early Iron Age in the eastern Baltic: an archaeobotanical case study of the lakeshore settlement Luokesa 1, Lithuania
}

\author{
Britta Pollmann
}

Received: 8 August 2013/Accepted: 24 April 2014/Published online: 20 May 2014

(C) Springer-Verlag Berlin Heidelberg 2014

\begin{abstract}
Prehistoric agriculture and vegetation in Lithuania have so far been reconstructed largely using palynological data. This paper reports the archaeobotanical investigation of macroremains from the Late Bronze-early Iron Age (LBA-EIA) lakeside settlement Luokesa 1 (L1) in eastern Lithuania, with the aim of elucidating the settlement's history and crop diversity. The single phase settlement was fortified with an onshore palisade and is dated between 625 and 535 cal. BC. Samples were taken along a land to lake transect, and in the centre of L1. The stratigraphy consisted of three distinct layers: lake marl, cultural deposit and sandy limnic sediment on top. The plant spectrum shows that L1 was constructed on an exposed morainic shoal. It was surrounded by woodland, meadows, fields/gardens, ruderal habitats and riverine vegetation. Accumulated cultural deposits consisted mainly of manure (litter, fodder and dung of sheep/goat), with rubbish, sweepings from the houses or remains of the onsite vegetation. The crops were Panicum miliaceum, Triticum spelta, T. dicoccon, Hordeum vulgare s.l., Pisum sativum and Camelina sativa, the latter being the first prehistoric evidence in Lithuania. The trophic state of the lake increased during the occupation period. After the abandonment of the settlement the ruins decayed until the lake flooded the site. The results are discussed in a broader
\end{abstract}

Communicated by M. Latałowa.

Electronic supplementary material The online version of this article (doi:10.1007/s00334-014-0464-0) contains supplementary material, which is available to authorized users.

B. Pollmann $(\bowtie)$

Integrative Prehistory and Archaeological Science (IPAS), University of Basel, Spalenring 145, 4055 Basel, Switzerland e-mail: bpollmann@yahoo.de context of the LBA/EIA cultures in northern Central Europe.

Keywords Archaeobotany - Wetland site - Waterlogged preservation · Dung of sheep/goat · Camelina sativa . Animal husbandry $\cdot$ Crops

\section{Introduction}

Prehistoric lakeside settlements are well known from many parts of Europe, dating from the Neolithic to the early Iron Age (Menotti 2004; Pranckenaite 2011; Menotti and O'Sullivan 2013). The construction of buildings and platforms at wetland sites is not restricted to a single archaeological culture, but is a diachronic phenomenon in the context of hinterland and dry land occupation and as an adaptation to wet conditions at rivers, lakes, the coast or bogs (Ebersbach 2013).

There are typological differences between wetland settlements of the Late Bronze-early Iron Age (LBA-EIA) in Europe (Menotti 2004; Menotti and O'Sullivan 2013; Pranckénaite 2014). In Britain settlements were constructed on artificial islands (crannogs) or on free-standing wood piles (Henderson 1998; Dixon 2004). In northern Central Europe, as in Poland, other artificial structures (scaffolding platforms) are known, as from Orzysz or Mołtajny; furthermore, other types of settlements enclose fortified areas of different sizes as at Boguszewo, Grodno, Sobiejuchy or Biskupin (Harding et al. 2004; Pydyn and Gackowski 2011). In Estonia only a few wetland settlements are known so far and often the type of construction is still unclear (Kriiska and Roio 2011). In Latvia no wetland sites dated to the LBA-EIA have been found until now (Loze 2011). Wooden houses, with or without raised floors on piles are very well known 
from southern Central Europe, as in Switzerland or southern Germany (e.g. Kimmig 1992; Gollnisch-Moos 1999).

Due to waterlogged conditions, the preservation of organic material in the cultural deposits of these wetland sites is exceptionally good, providing a great opportunity to study the palaeoenvironment, economy and everyday life of the inhabitants (Jacomet 2013). During decades of research the methodology for sampling, processing and analysing of waterlogged cultural deposits by means of plant macroremains has been refined and adapted to the exceptional conditions (Jacomet 1985; Hosch and Zibulski 2003; Jacomet and Brombacher 2005; Vandorpe and Jacomet 2007; Tolar et al. 2010; Maier and Harwath 2011).

\section{State of research in Lithuania in the context of northern Central Europe}

Archaeobotanical research has been carried out for decades in northern Central Europe. Archaeobotanical research in Lithuania covers the time span from the Neolithic up to modern times, but is - in comparison to other parts of Central Europe-still in a pioneer phase (Antanaitis-Jacobs et al. 2002), focussing on sites with mineral soils of the Middle Ages and more recent periods, for example the prosperous times of Vilnius lower castle and Klaipeda old town (Stančikaitė et al. 2008, 2012; Masiulienè 2009; Kisielienė et al. 2012). Archaeobotanical data on prehistoric wetland sites in Lithuania are published from the Neolithic sites of Žemaitiškè (near Lake Kretuonas) and Šventoji (AntanaitisJacobs et al. 2002; Antanaitis-Jacobs and Stančikaite 2004; Stančikaite et al. 2004, 2009; Rimantienè 2005; Girininkas 2008), the LBA-EIA sites of Turlojiškè (Antanaitis-Jacobs et al. 2004) and Lake Luokesa (Motuzaite Matuzevičiūte 2007) and from the Iron Age "foot settlement" of the Juodonys hillfort, now a dry-land site (Daugnora et al. 2004). The closest wetland sites of the LBA-EIA in the neighbouring countries are those of northern and central Poland (Pydyn and Gackowski 2011), where archaeobotanical and pollen analyses have been carried out (e.g. Harding et al. 2004; Haas and Wahlmüller 2010; Latałowa and Pińska 2010; Pydyn and Gackowski 2011).

Today the reconstruction of Lithuania's agriculture in the transitional period from LBA to EIA is mainly based on palynological data and also includes data from the other Baltic states (Antanaitis-Jacobs and Stančikaite 2004). These are supplemented by results such as those of plant macro remain research, ancient field typology, implements interpreted as agricultural tools, or imprints in ceramics known from Scandinavia and Estonia (Lang 2007; Merkevičius and Nemickiene 2011). Based on these data, the agriculture in northern Central Europe at the time of the occupation of Luokesa 1 (L1) can be described as follows:
Towards the transition from the LBA to EIA (about $600-400 \mathrm{BC}$ ), the agricultural practices changed and permanent fields were established (Gaigalas 2004; Lang 2007). Human impact on the environment increased, indicated by higher percentages of cereal pollen and by other indicators of open landscape (Antanaitis-Jacobs and Stančikaitė 2004; Stančikaitè et al. 2004; Wacnik 2009; Haas and Wahlmüller 2010; Bogucki 2013). Because of the large amount of micro-charcoal in palynological samples and layers of charcoal particles underneath the clearance cairns of fossil fields, slash and burn probably took place in this period (Gaigalas 2004; Lang 2007). Furthermore, Lang (2007) suggests for Estonia that cultivated fields were left fallow after a few years, and new fields were established elsewhere, and fields were probably fertilised.

The crops in northern Central Europe at that time were mainly Hordeum vulgare (barley) followed by Triticum monococcum/dicoccon/spelta (hulled wheats), Panicum miliaceum (broomcorn millet) and T. aestivum/durum/turgidum (naked wheats), less abundant were Avena sativa (oat) and Secale cereale (rye). The pulses were Pisum sativum (pea), Lens culinaris (lentil) and Vicia faba (horse bean). The oil plants were Linum usitatissimum, Camelina sativa (gold-of-pleasure), Spergula arvensis (corn spurrey), Papaver somniferum (opium poppy) (Wasylikowa et al. 1991; Poska et al. 1999; Lang 2007; Karg 2012; Stika and Heiss 2012).

\section{Study area}

Lake Luokesa (Luokesai ežeras) is located in the lake district of eastern Lithuania in the Baltic Highlands (Fig. 1), which was formed during the last Ice Age (Motuzaite Matuzevičiūtè 2008; Guobyte and Satkūnas 2011; Pranckènaite 2014). The area is characterised today by undulating moraines and many lakes (Menotti et al. 2005), most of which are connected by small channels or flowing groundwater (Kunskas 2005). The soils to the east of Lake Luokesa are mainly arenosols, gleyic podzols and eutic histosols, while in the west albeluvisols, various luvisols and gleyic cambiosols can be found, which are more suitable for agriculture (Soil Atlas of Europe 2005).

Today, Lake Luokesa lies in the northern temperate zone with a continental, semi-humid climate (Lauer and Frankenberg 1988). L1 was occupied in the transition from the chronozone Subboreal to Subatlantic based on absolute radiocarbon dating, similarly the pollen spectrum places the occupation period in the early Subatlantic (Damušyte 2011; Heitz-Weniger 2014). At about 750 cal. BC one of the most distinct warming periods in eastern Central Europe began, followed by a cooling period at about 550 cal. BC 


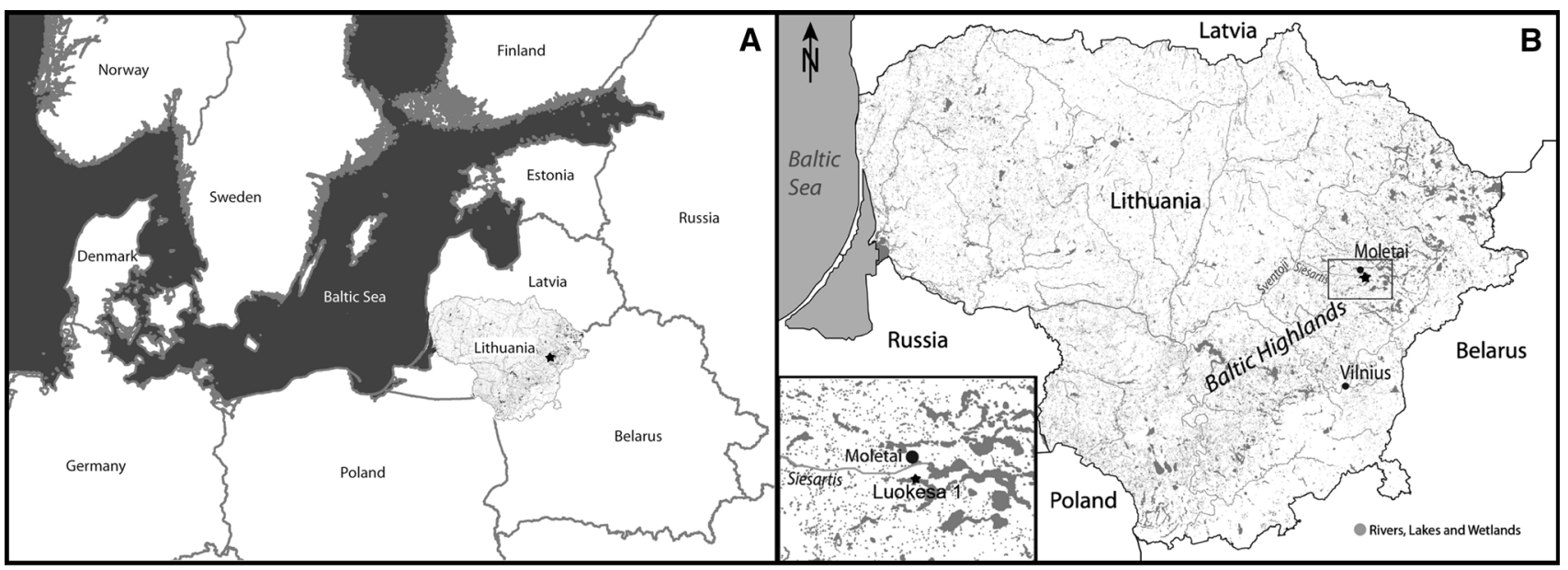

Fig. 1 A, Location of Lake Luokesa (Luokesai ežeras) in northern Europe; B, Map of Lithuania with lakes, wetlands and rivers (grey). Lake Luokesa is indicated by a star. The inserted map shows Lake

(Gaigalas 2004; Sillasoo et al. 2009). Therefore, L1 was occupied towards the end of a warmer period.

The natural vegetation today is mainly woodland on the highlands and swamps in the lowlands. In general, Picea and mixed woods dominate on till areas; in contrast Pinus prevails on sandy ground. Along the streams, rivers or lakes riverine vegetation covers the slopes of the moraines. The lower areas are wetter, and the depressions are covered by peat bogs (Menotti et al. 2005; Soil Atlas of Europe 2005; Tupčiauskaitė 2012).

\section{The site L1}

Lake Luokesa ( $\mathrm{N} 55^{\circ} 12.37^{\prime}$, E $025^{\circ} 25.000^{\prime}, 144 \mathrm{~m}$ a.s.l.) is about $2.4 \mathrm{~km}$ wide and $0.8 \mathrm{~km}$ long and has a maximum depth of $47 \mathrm{~m}$ (Menotti et al. 2005). Two archaeological sites on Lake Luokesa, L1 and L2, were discovered during an underwater archaeological survey in 2000/2001 (Fig. 2; Baubonis et al. 2001; Baubonis et al. 2002; Pranckenaite 2014). No archaeobotanical analyses have been carried out on L2 so far. L1 is dated between 625 and 535 cal. BC by dendrochronology and wiggle matching, and lasted for at least 16 , but probably not more than 20 years (Bleicher 2014). The single phase lakeside settlement was built on a morainic shoal and fortified with a double fenced, onshore palisade. House plans cannot be reconstructed so far. The central part of $\mathrm{L} 1$ covers about $900 \mathrm{~m}^{2}$ (ca. $20 \times 30 \mathrm{~m}$ ), while the area which is enclosed by the palisade is about $1,800 \mathrm{~m}^{2}$ (ca. $40 \times 60 \mathrm{~m}$ ) (Pranckenaite 2012). The settlement belongs to the Brushed Pottery Culture on the basis of the archaeological finds (Brazaitis 2005; Pranckennaite 2012, 2014).
Luokesa with the site L1 (star); the coordinates of Lake Luokesa are $\mathrm{N} 55^{\circ} 12.37^{\prime}, \mathrm{E} 025^{\circ} 25.000$ ', $144 \mathrm{~m}$ a.s.l. (map by E. Pranckènaite, modified by K. Ismail-Meyer and B. Pollmann)

The data presented here are used to draw conclusions on the type of construction of the settlement, the formation of the cultural deposits and the palaeoenvironment and economy; only part of a larger archaeobotanical investigation on macroremains of the lakeshore settlement L1 is given here, the remaining data will be the subject of other papers which are in preparation. The results are discussed within a broader context by comparison with archaeobotanical results from northern Central Europe and taking the role of Camelina sativa especially into account.

\section{Material and methods}

Sampling and processing of the samples

In 2008/2009 in total 25 profile columns, 57 surface samples and 63 judgment samples/hand collected finds were collected from L1 by archaeological divers. The sampling strategy was adapted to underwater excavation conditions and very loose sediment using the normal methods for wetland sites in the circum-alpine region (Jones 1991; Jacomet and Brombacher 2005; Maier and Harwath 2011; Jacomet 2013). Systematic surface samples, judgment samples and sediment cores were collected directly from the $8 \mathrm{~m}^{2}$ excavation area. To obtain sediment cores, $11 \mathrm{~cm}$ diameter tubes were driven into the lake sediment at the beginning and were left there until the end of the excavation in order not to disturb the archaeological record by removing them. Additional sediment cores were taken from a larger area in the centre of L1 and from a lake-landtransect (Fig. 3) and removed subsequently. The profile columns were covered with a fine meshed netting to 


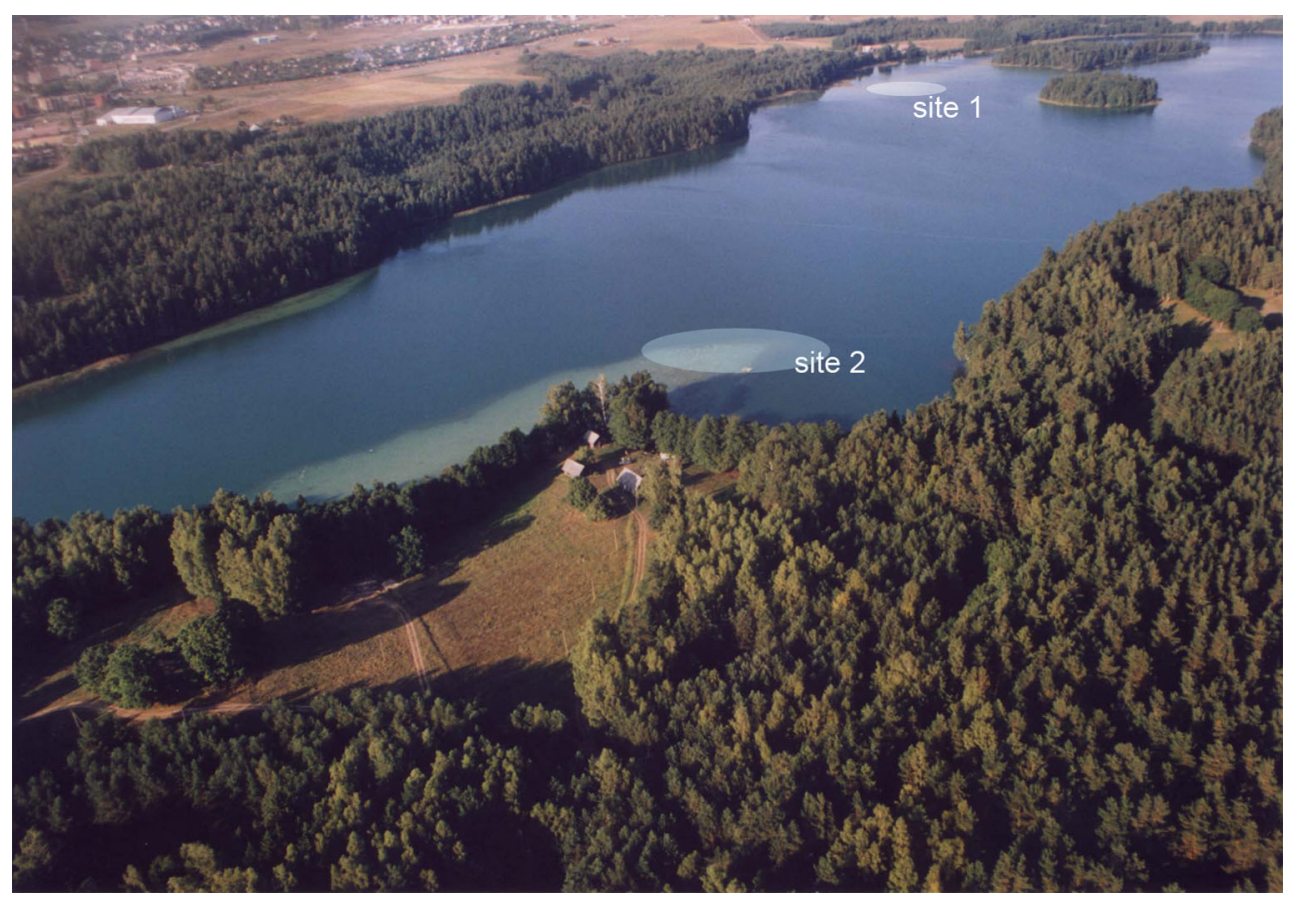

Fig. 2 Aerial photo of Lake Luokesa, Moletai district (view from southwest to northeast) with the archaeological sites L1 and L2 (photo provided by E. Pranckènaitè)

prevent the accumulation of floating material in the columns. Once on land, the sediment cores were drained, sealed and transferred to IPAS at Basel, Switzerland.

After opening the columns in the laboratory, the surface of the sediment was cleaned and the stratigraphy was described by geoarchaeologists (Ismail-Meyer 2014). Nine profiles (centre and transect) were chosen for archaeobotanical investigations (LALU 2, 4, 13, 15 and 101 to 105; Fig. 3) The dissection of the sediment cores followed the method described by Jacomet (1985) and Jacomet et al. (1989). Additionally, four surface samples were investigated.

The further processing was the same for both the profile samples and surface samples. The samples were wet sieved with $2,0.5$ and $0.25 \mathrm{~mm}$ mesh sizes using the wash-over method (Kenward et al. 1980, modified by others, e.g. Hosch and Zibulski 2003; Kabailiene 2006; Vandorpe and Jacomet 2007; Tolar et al. 2010). Pieces of very dense sediment were left intact. If dung remains and artefacts were recognised by eye during semi-flotation they were sampled separately.

Analyses of botanical macroremains

The samples were finally sorted using a Leica/Wild Heerbrugg stereo microscope with a 5 to $50 \times$ magnification; for identification a magnification up to $100 \times$ was used. Very rich samples were subsampled. Counting units were defined (Vandorpe and Jacomet 2007), for example for the quantification of chaff and grains; in the latter case only testa fragments with (parts of) hilum were counted. All countable remains like seeds, fruits, chaff, seed, pods/siliquae or others were fully quantified. The abundance of other remains like charcoal, wood fragments, twigs, roots/rhizomes, leaves, mosses or bark was semi-quantitatively estimated after Bullock et al. (1985). Identifications were made using the reference seed collection of IPAS and identification literature (e.g. Jacomet et al. 1989; Maier 2004; Cappers et al. 2006; Birks 2007). The nomenclature of scientific plant names follows Flora Helvetica (Lauber et al. 2012) or, for taxa not included there, the Lithuanian flora (Vilkonis 2008). The affiliation of the taxa into ecological groups follows Brombacher and Jacomet (1997), which is based on ecological indicator values by Ellenberg (1991).

Radiocarbon dating

In total 12 organic remains from four of the investigated profiles were AMS ${ }^{14} \mathrm{C}$ dated by the Laboratory of the Eidgenössische Technische Hochschule (ETH) Zürich, Switzerland (for more details see Heitz-Weniger 2014, Table 2).

\section{Results}

In total, 117 samples from nine profiles, four surface samples and 16 hand-collected finds were analysed (ESM 1). About 30,000 macroremains from more than 190 taxa 


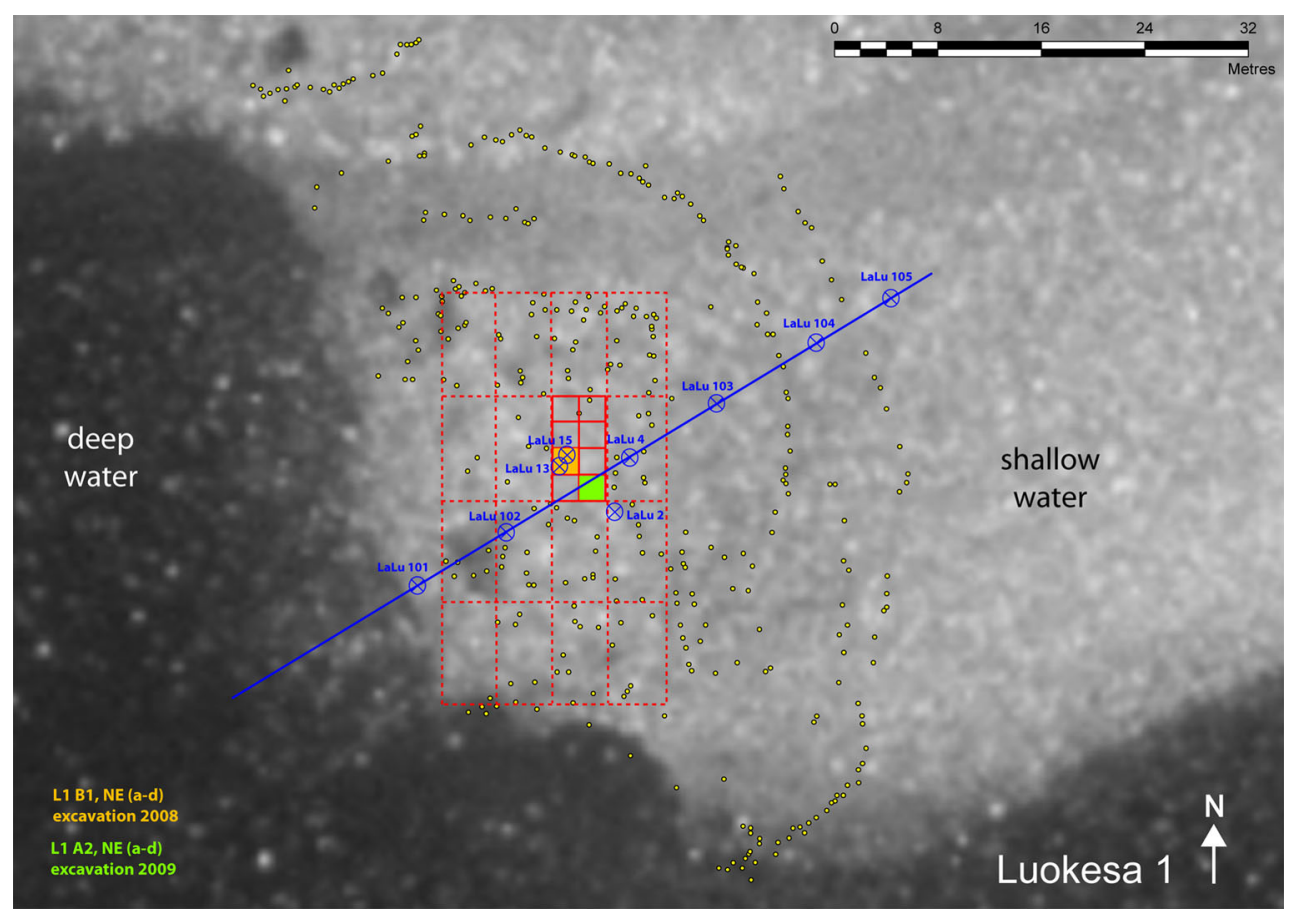

Fig. 3 Aerial photo of L1, excavation grid (red grid) with excavation areas of 2008 and 2009 (orange and green squares), the places where archaeobotanical samples were taken, land-lake transect (blue line), positions of sediment cores (blue circles with cross) and wooden piles (yellow dots)

were recorded and evaluated quantitatively. More than $90 \%$ of the remains were preserved in a waterlogged state. The preservation of organic matter was excellent, but subject to fluctuations.

The stratigraphy of the lakeshore settlement L1 includes three different types of deposits: lake marl at the bottom, the cultural deposits of L1 in the middle and sandy limnic sediment on top. The taxa spectra and the composition of the samples differ considerably between the three types of deposits, as described below (Fig. 4). The stratigraphy is described, mainly based on profile LALU 15 , because it is the most representative one for the whole stratigraphy, is located in the centre of the lakeshore settlement with a more than $60 \mathrm{~cm}$ thick cultural deposit and is composed of all three layers (ESM 2, 3).

The lowermost part of the stratigraphy: the lake marl

The ${ }^{14} \mathrm{C}$ dates show that the lake marl built up at least from $4075 \pm 105$ cal. BC onwards (82.5\%, bark, ETH-42984), until it was covered by the cultural deposits dated $660 \pm 140$ cal. BC $(95.4 \%$, hazelnut, ETH-42980, for complete data set see Heitz-Weniger 2014, Table 2). The greyish lake marl consisted of various layers separated by thin layers of mollusc remains. The concentration of macroremains was low, about 300 remains/l in profile LALU 15, fraction 2 and $0.5 \mathrm{~mm}$ (ESM 2). The sediment contained mainly small water molluscs and a few insect remains, particularly caddis fly larval cases (Trichoptera), Bryozoa statoblasts, egg cocoons of Piscicola geometra (fish leech), a few particles of charcoal and bark, coniferous needles and some diaspores, including oospores of Characeae. The plant spectrum was dominated by wind or water-distributed remains of the on-shore vegetation, such as fruits of Betula pendula/pubescens (birch), needles of Pinus sylvestris (pine) and Picea abies (spruce), or water plants such as Characeae and Najas marina, $N$. intermedia (naiads) (Table 1, ESM 2). Some of the limnic indicators such as $N$. marina and $N$. intermedia have ecological requirements typically for oligotrophic to mesotrophic and rather calm water (Ellenberg 1991).

The interface from the lake marl to the cultural deposits was quite sharp, indicated by two different sediment colours visible by naked eye (Fig. 4), even though a slight mixing was observed for example as glumes of Panicum miliaceum appeared in the upper part of the lake marl and the lower parts of the cultural deposits were characterized by a few water molluscs, Bryozoa statoblasts and oogonia of Characeae (ESM 3).

The cultural deposits

The ${ }^{14} \mathrm{C}$ dates of the cultural deposits obtained from macroremains correspond to the dates achieved by the wiggle matching and dendrochronology of $625-535 \mathrm{cal}$. BC (Bleicher 2014). They show that the cultural deposits are 
Profiles of the settlement's centre

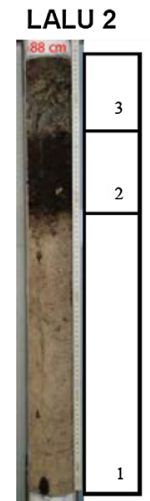

$88 \mathrm{~cm}$

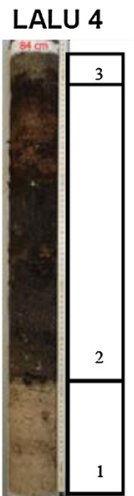

$84 \mathrm{~cm}$

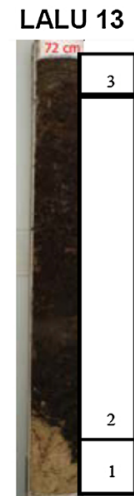

$72 \mathrm{~cm}$

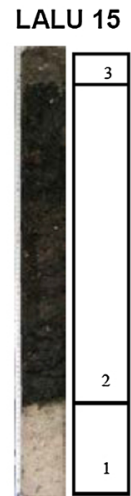

$86 \mathrm{~cm}$
Profiles of the lake-land transect, LALU 102 is also from the settlement's centre

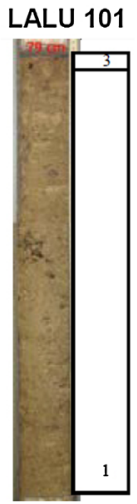

$79 \mathrm{~cm}$
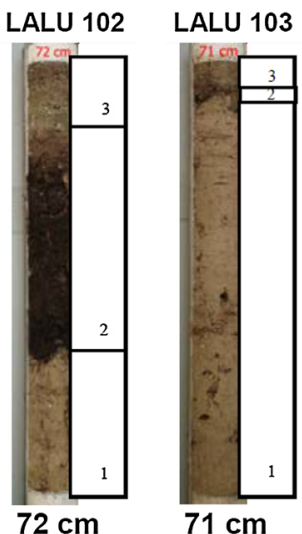

$71 \mathrm{~cm}$

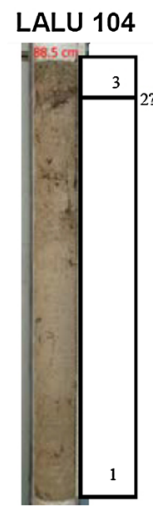

$88.5 \mathrm{~cm}$

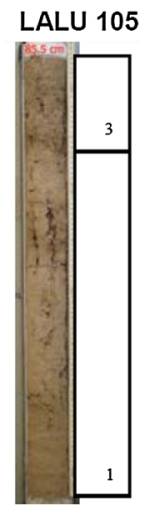

$85.5 \mathrm{~cm}$

Fig. 4 Sediment cores LALU 02, 04, 13, 15 and 101 to 105. 1, the deposits of lake marl; 2, cultural deposits; 3, sandy limnic sediment are marked

contemporary with the piles of the settlement (for details, Bleicher 2014; Heitz-Weniger 2014). In general, the closer to the centre of L1, the thicker were the cultural deposits. In the most distant profiles of the transect (cores LALU 101 and 105, Fig. 3), only lake marl and sandy lake sediment were found. The cultural deposits were between a few $\mathrm{cm}$ and up to more than $60 \mathrm{~cm}$ thick, and rich in macroremains (about 8,000 remains/1, 2 and $0.5 \mathrm{~mm}$ fraction, LALU 15, ESM 2). The lowest layer of the cultural deposit, representing the early phase of house construction, contained more and larger fragments of charcoal, bark and wood chips, often laid horizontally, than were found in the layers above. Overall, the cultural deposit consisted mainly of wood chips, bark, charcoal, stems, chaff and fruits/seeds of wild and cultivated plants (ESM 3). Less frequent but still abundant were fragments of leaves/needles/fronds, buds/ bud scales and catkin scales, clearly recognisable dung of sheep/goat and fly pupae. All samples were penetrated by rhizomes and adventitious roots of Phragmites australis (reed). In a few samples other unidentified lignified roots or aggregations of rootlets were also found. More than $90 \%$ of the organic remains were in a waterlogged condition; in some samples from various profiles the amount of carbonised or partially carbonised items increased up to ca. $15 \%$ (LALU 15-17 or 15-22 or LALU 13-09).

Based on absolute numbers, the plant spectrum is dominated by remains of crops, which belong to six taxa: Panicum miliaceum, Triticum spelta, T. dicoccon, Hordeum vulgare (multi-rowed), Camelina sativa and Pisum sativum (Table 1). The prevalent taxa in the cultural deposits were $P$. miliaceum (ubiquity of $91 \%$ ) and $C$. sativa (ubiquity of $88 \%$ ), hulled wheat (ubiquity of $81 \%$ ) and Triticum dicoccon (ubiquity of 79\%) (Table 2). Different types of remains were found either in waterlogged, partially carbonised or carbonised preservation such as chaff (spikelet fork, glume base, glume, rachis, rachilla), testa/ caryopses, seeds and siliquae (Table 3). The amount of chaff of cereals and Camelina was clearly more than the number of caryopses/seeds. For example in profile LALU 15 (ESM 2) the ratio is about 8:1 for larger seeded cereals except Panicum, about 16:1 for Panicum (ratio of glumes with base to testa/hilum of the caryopsis) and about 4:1 for Camelina siliquae and seeds.

The spectrum of wild plants includes more than 180 taxa that could be assigned to eight different ecological and use groups (Fig. 5). The weed spectrum of L1 includes 23 taxa and $91 \%$ of the taxa are weeds of summer cereals/root crops or ruderal plants (for example Arenaria serpyllifolia, Chenopodium album, Polygonum persicaria or Sonchus arvensis), while $9 \%$ are weeds of winter cereals (Fallopia convolvulus).

Less frequent are edible wild plants such as Fragaria sp. (strawberry), Rubus idaeus (raspberry), R. fruticosus agg. (blackberry), R. saxatilis (stone bramble) and Corylus avellana (hazelnut). Other plants might also have been used for human consumption or medical purposes like Hypericum perforatum (common St. John's wort), Tilia cordata (lime), Frangula alnus (buckthorn) or Urtica dioica (nettle). Tilia and Urtica have also the potential to provide raw material for textile production.

The frequency of meadow plants represented is remarkable, for example shown by the broad spectrum of various Trifolium sp. (clover) remains such as petals, calyces, fruits and, in some cases, calyces with unripe fruits or by Centaurea scabiosa s.l. (greater knapweed) with seeds, bracts or even whole flower heads.

Riverine plants (e.g. Filipendula ulmaria) and water plants (e.g. Trapa natans) were present in the cultural deposits, but not very abundant (Table 1). The remains of T. natans were highly fragmented. In contrast to the lake 
Table 1 Water plants found in L1 in the three types of deposits: lake marl, cultural deposits, sandy limnic cover (counted number of remains and ubiquity), the ecological requirements of the water plants are different according to the trophic state: white $=$ oligo- to mesotrophic conditions, grey $=$ meso- to eutrophic conditions (Ellenberg 1991)

\begin{tabular}{|c|c|c|c|c|c|c|c|c|c|}
\hline Taxa & Type & Preserv. & $\Sigma($ total $)$ & $\begin{array}{r}\Sigma \text { remains, } \\
\text { lake marl }\end{array}$ & $\begin{array}{l}\Sigma \text { remains, } \\
\text { cult. layer }\end{array}$ & $\begin{array}{l}\Sigma \text { remains, } \\
\text { sandy cover }\end{array}$ & $\begin{array}{l}\text { Ubiquity, } \\
\text { lake marl }\end{array}$ & $\begin{array}{l}\text { Ubiquity, } \\
\text { cult. layer }\end{array}$ & $\begin{array}{l}\text { Ubiquity, } \\
\text { sandy cover }\end{array}$ \\
\hline Characeae & oogonia & waterlogged & 1,558 & 1,305 & 80 & 172 & 21 & 7 & 35 \\
\hline Najas sp. & seed/fruit & waterlogged & 38 & 31 & & 7 & 10 & & 10 \\
\hline Najas sp. & seed/fruit & partly carb. & 1 & & 1 & & & 2 & \\
\hline Najas intermedia & seed/fruit & waterlogged & 5 & 2 & & 3 & 3 & & 10 \\
\hline Najas marina & seed/fruit & waterlogged & 46 & 39 & 2 & 4 & 31 & 3 & 20 \\
\hline Nuphar/Nymphaea & seed/fruit & waterlogged & 4 & & & 4 & & & 5 \\
\hline Nuphar sp. & seed/fruit & waterlogged & 2 & & & 2 & & & 10 \\
\hline Nuphar lutea & seed/fruit & waterlogged & 4 & & 1 & 3 & & 2 & 15 \\
\hline Nymphaea sp. & seed/fruit & waterlogged & 13 & & 8 & 5 & & 10 & 10 \\
\hline Nymphaea alba & seed/fruit & waterlogged & 6 & & 1 & 5 & & 2 & 20 \\
\hline Potamogeton sp. & seed/fruit & waterlogged & 12 & 1 & 6 & 5 & 2 & 10 & 15 \\
\hline Trapa natans & fruit & waterlogged & 13 & & 12 & 1 & & 7 & 5 \\
\hline
\end{tabular}

Table 2 Ubiquity of crops in L1, based on all sediment samples (profile and surface samples)

\begin{tabular}{llll}
\hline & $\begin{array}{l}\text { Lake } \\
\text { marl (\%) }\end{array}$ & $\begin{array}{l}\text { Cult. } \\
\text { layer (\%) }\end{array}$ & $\begin{array}{l}\text { Covering limnic } \\
\text { sediment (\%) }\end{array}$ \\
\hline Camelina (sativa) & & 88 & 45 \\
Cerealia & & 93 & 20 \\
Hordeum vulgare & & 65 & 15 \\
Panicum miliaceum & 3 & 91 & 30 \\
Triticum dicoccon & & 79 & 50 \\
Triticum spelta & 70 & 25 \\
Hulled wheat & 81 & 35 \\
Fabaceae (cultivated) & 58 & 25 \\
Pisum sativum & 35 & 10 \\
\hline
\end{tabular}

marl below, the cultural deposits contained water plants indicative of meso- or eutrophic water (e.g. Nuphar lutea; Table 1).

Overall there was an increasing amount of decay of the organic material such as wood chips and chaff which was recognisable from the middle to the top of the cultural deposits.

The lake sediment on top of the cultural layer

The lake sediment on top of the cultural deposits was sandier than the lake marl below and did not have a clear stratigraphy, but contained relocated material from the cultural layer. The influence of the lake on the sediment is indicated by seeds/fruits of water plants, oogonia of
Characeae and statoblasts of Bryozoa. The seeds/fruits of water plants (e.g. Najas sp., Nymphaea sp.) or fresh water marshes (e.g. Schoenoplectus lacustris) were more frequent in the sandy cover than in the cultural deposit and indicate meso-/eutrophic water (e.g. Nuphar lutea; Table 1). Additionally fresh water sponges and Dreissena polymorpha (zebra mussel), a neozoon, were found in the upper part (ESM 3). Therefore, the sandy limnic cover is a disturbed layer containing remains from the LBA-EIA deposits together with more modern material.

Throughout the whole stratigraphy, rhizomes and adventitious roots of Phragmites australis were found (ubiquity $100 \%$ ) and especially an in situ record of a reed plant in profile LALU 101 proved that reeds grew there at later times $\left({ }^{14} \mathrm{C}\right.$ dated between cal. $\mathrm{AD} 1660$ and 1960, 95,4\%, ETH-42988).

\section{Discussion}

Since the samples were taken along a transect from land to lake through the centre of the settlement and from the centre itself, they are considered as being representative of the different types of deposits, lake marl, cultural deposits and sandy limnic cover. On the basis of the investigated samples and the number of identified macroremains it is therefore possible to draw conclusions about the composition of the deposits and the origins of the various types of material, the environment and the crop plants. Even if the proportion of the taxa might not be representative of the whole settlement and if intra-site patterns cannot be evaluated by this method, the results are still important for 
Table 3 Crop plants found in L1, based on all sediment samples (profile and surface samples). The preservation state, counts and ubiquity are listed; $($ part $)$ carb $=$ (partially) carbonised; waterl $=$ waterlogged

\begin{tabular}{|c|c|c|c|c|c|c|c|c|c|}
\hline & Type & Preserv. & $\Sigma($ total $)$ & $\begin{array}{r}\Sigma \text { remains, } \\
\text { lake marl }\end{array}$ & $\begin{array}{l}\Sigma \text { remains, } \\
\text { cult. layer }\end{array}$ & $\begin{array}{l}\Sigma \text { remains, } \\
\text { sandy cover }\end{array}$ & $\begin{array}{l}\text { Ubiquity, } \\
\text { lake marl }\end{array}$ & $\begin{array}{l}\text { Ubiquity, } \\
\text { cult. layer }\end{array}$ & $\begin{array}{l}\text { Ubiquity, } \\
\text { sandy cover }\end{array}$ \\
\hline Camelina sativa & seed & waterl & 51 & & 50 & 1 & & 22 & 5 \\
\hline Camelina sp. & seed & waterl & 309 & & 297 & 12 & & 44 & 15 \\
\hline Camelina sp. & silique & waterl & 1,555 & 1 & 1,488 & 66 & 2 & 61 & 45 \\
\hline Camelina sp. & stem (apical end) & waterl & 6 & & 6 & & & 7 & \\
\hline Cerealia & testa with hilum & waterl & 1,121 & & 1,110 & 11 & & 54 & 15 \\
\hline Cerealia & chaff & waterl & 1,740 & & 1,702 & 38 & & 56 & 15 \\
\hline Fabaceae (cult.) & seed/fruit & waterl & 278 & & 263 & 15 & & 42 & 15 \\
\hline cf. Fabaceae (cult.) & seed/fruit & waterl & 4 & & & 4 & & & 10 \\
\hline Hordeum vulgare & rachis & waterl & 130 & & 126 & 4 & & 39 & 10 \\
\hline Panicum miliaceum & glume & waterl & 88 & & 88 & & & 7 & \\
\hline P. miliaceum & glume with basis & waterl & 4,393 & 6 & 4,178 & 209 & 3 & 61 & 30 \\
\hline P. miliaceum & just hilum & waterl & 109 & & 101 & 8 & & 37 & 15 \\
\hline P. miliaceum & caryopsis without glume & waterl & 24 & & 24 & & & 12 & \\
\hline P. miliaceum & caryopsis with glume & waterl & 756 & & 730 & 26 & & 56 & 30 \\
\hline Pisum sativum & seed/fruit with hilum & waterl & 41 & & 39 & 2 & & 19 & 10 \\
\hline P. sativum & hilum & waterl & 1 & & 1 & & & 2 & \\
\hline cf. Triticum sp. & rachis & waterl & 20 & & 20 & & & 10 & \\
\hline T. di./monoc./spelta & chaff & waterl & 3,014 & & 2,926 & 88 & & 59 & 30 \\
\hline T. dicoccon & glume base & waterl & 2,448 & & 2,386 & 62 & & 56 & 40 \\
\hline T. dicoccon & testa and spikelet fork & waterl & 10 & & 10 & & & 8 & \\
\hline T. dicoccon & spikelet fork & waterl & 873 & & 849 & 24 & & 54 & 25 \\
\hline$T$. cf. monococcum & glume base & waterl & 36 & & 35 & 1 & & 8 & 5 \\
\hline T. cf. monococcum & spikelet fork & waterl & 39 & & 39 & & & 10 & \\
\hline T. spelta & glume base & waterl & 522 & & 502 & 20 & & 51 & 20 \\
\hline T. spelta & spikelet fork & waterl & 54 & & 53 & 1 & & 29 & 5 \\
\hline T. cf. spelta & glume base & waterl & 3 & & 3 & & & 2 & \\
\hline Total crops waterl. & & & 17,625 & 7 & 17,026 & 592 & & & \\
\hline Camelina sp. & seed & carb & 2 & & 2 & & & 3 & \\
\hline Camelina sp. & silique & carb & 1 & & 1 & & & 2 & \\
\hline Cerealia & caryopsis & carb & 10 & & 9 & 1 & & 10 & 5 \\
\hline Cerealia & embryo & carb & 1 & & 1 & & & 2 & \\
\hline Cerealia & chaff & carb & 31 & & 31 & & & 15 & \\
\hline Fabaceae (cult.) & seed/fruit & carb & 9 & & 9 & & & 5 & \\
\hline Hordeum vulgare & rachis & carb & 12 & & 12 & & & 7 & \\
\hline H. vulgare & rachilla & carb & 1 & & 1 & & & 2 & \\
\hline H. vulgare & caryopsis & carb & 12 & & 9 & 3 & & 12 & 10 \\
\hline cf. H. vulgare & caryopsis & carb & 2 & & 2 & & & 3 & \\
\hline Panicum miliaceum & glume & carb & 480 & 4 & 476 & & 2 & 29 & \\
\hline P. miliaceum & caryopsis & carb & 24 & & 24 & & & 10 & \\
\hline cf. $P$. miliaceum & caryopsis & carb & 1 & & 1 & & & 2 & \\
\hline Pisum sativum & seed/fruit with hilum & carb & 11 & & 11 & & & 5 & \\
\hline cf. $P$. sativum & seed/fruit & carb & 1 & & 1 & & & 2 & \\
\hline Triticum spec. & caryopsis & carb & 1 & & 1 & & & 2 & \\
\hline T. di./monoc./spelta & chaff & carb & 20 & & 20 & & & 8 & \\
\hline T. di./monoc./spelta & caryopsis & carb & 2 & & & 2 & & & 5 \\
\hline T. dicoccon/spelta & caryopsis & carb & 1 & & 1 & & & 2 & \\
\hline T. dicoccon & glume base & carb & 15 & & 15 & & & 17 & \\
\hline T. dicoccon & spikelet fork & carb & 2 & & 2 & & & 3 & \\
\hline T. dicoccon & caryopsis & carb & 3 & & 3 & & & 3 & \\
\hline T. cf. dicoccon & caryopsis & carb & 4 & & 2 & 2 & & 3 & 10 \\
\hline T. spelta & glume base & carb & 2 & & 1 & 1 & & 2 & 5 \\
\hline T. spelta & spikelet fork & carb & 3 & & 3 & & & 5 & \\
\hline Total crops carb. & & & 651 & 4 & 638 & 9 & & & \\
\hline Camelina sp. & silique & part carb & 1 & & 1 & & & 2 & \\
\hline Cerealia & embryo & part carb & 1 & & 1 & & & 2 & \\
\hline Cerealia & testa with hilum & part carb & 11 & & 11 & & & 2 & \\
\hline Cerealia & chaff & part carb & 2 & & 2 & & & 2 & \\
\hline Panicum miliaceum & glume & part carb & 170 & & 169 & 1 & & 17 & 5 \\
\hline P. miliaceum & caryopsis with glume & part carb & 29 & & 20 & 9 & & 8 & 15 \\
\hline Pisum sativum & hilum & part carb & 1 & & 1 & & & 2 & \\
\hline T. di./monoc./spelta & chaff & part carb & 3 & & 3 & & & 2 & \\
\hline T. dicoccon & glume base & part carb & 6 & & 6 & & & 7 & \\
\hline T. dicoccon & spikelet fork & part carb & 6 & & 6 & & & 7 & \\
\hline T. spelta & glume base & part carb & 8 & & 8 & & & 5 & \\
\hline$T$. cf. spelta & glume base & part carb & 2 & & 2 & & & 2 & \\
\hline Total crops part carb & & & 240 & & 230 & 10 & & & \\
\hline
\end{tabular}




\section{Total $(n=28,141)$}

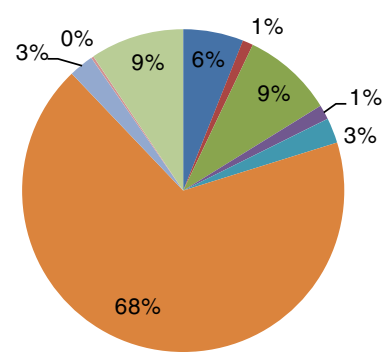

water

n swamp

wood

clear

meadow

m crop

rud1

rud2

var

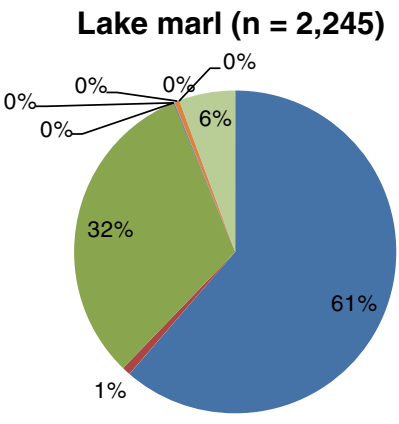

\section{water \\ nswamp \\ wood \\ - clear \\ meadow \\ - crop \\ rud1 \\ rud2 \\ var}

\section{Cultural deposits $(n=24,571)$}

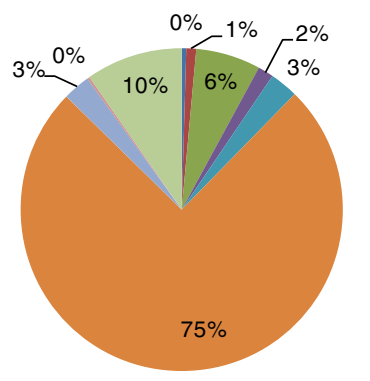

water

n swamp

wood

- clear

meadow

crop

rud1

rud2

var

\section{Sandy limnic cover $(n=1,325)$}

Fig. 5 Proportion of ecological and use groups based on absolute number of remains in L1. Abbreviations: 'water' = water plant communities, 'swamp' = lake shore/freshwater swamps/(seasonally) flooded plains, 'wood' = temperate deciduous and mixed woods, 'clear' = edge of the woodland, clearings, 'meadow' = grassland

knowledge of prehistoric agriculture in Lithuania. In terms of preservation, number of taxa and the overall composition of samples, the material from L1 is similar to sediments found in lakeside settlements of other regions (Jacomet 2013).

Where was the settlement built: on land or in the water?

Prehistoric wetland settlements show various types of construction (Menotti 2012; Menotti and O'Sullivan 2013). There were houses built on piles in the water, as well as houses erected on exposed morainic shoals or on artificial islands (Menotti and O'Sullivan 2013). For L1 the first geoarchaeological analysis argues that L1 was constructed "either on the lake bed in the water, or that piles were driven through a swampy land surface" (Lewis 2007), which was contradicted by Motuzaite Matuzevičiūte (2008) who proposed construction on land. Based on plant macroremains, I argue that the buildings were erected on the exposed morainic shoal, because there is a clear separation between lake marl and cultural deposits in terms of colour of the sediment and the distribution of plant taxa and other types of material, such as fish remains, charcoal and stones. Just a little intermixture between the sediments was observed, which is much more likely to have been the

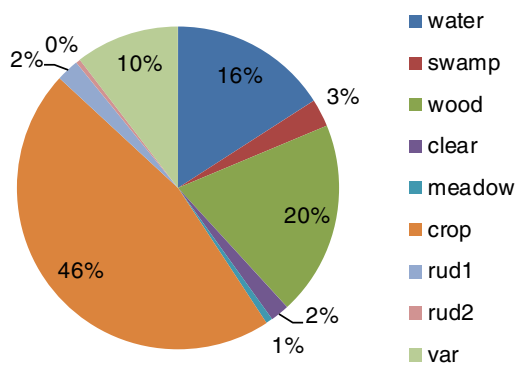

communities/meadows, 'crop' = crops (cereals, legume, oil plants), 'rud1' = weeds/short living vegetation of ruderal sites, 'rud2' = persistent vegetation on ruderal sites/nutrient-rich disturbed places, var $=$ origin from various habitats possible (compare ESM 2)

result of trampling than of water action (Ismail-Meyer and Rentzel 2004). Typical seeds/fruits of water plants and wind-distributed plants, which indicate precipitation of these on to sediments covered with water, dominate in the lake marl, whereas the percentage of these remains is much reduced in the cultural deposits. The composition of the cultural deposits clearly indicates residues of human activities and their livestock, and not the "peaty layer" proposed by Lewis (2007). There are no indicators for dominating on-site riverine vegetation during this time. The results of the micromorphological and palynological data confirm this assumption (Heitz-Weniger 2014; IsmailMeyer 2014). Summarizing, L1 was built on an exposed morainic shoal, and can be called a lakeshore settlement.

The cultural deposits at L1 compared to other wetland sites and LBA-EIA cultures in northern Central Europe

The characteristic composition of the lowermost layer, consisting of horizontally layered bark, charcoal and wood chips, has also been found at other lakeshore settlements (Ismail-Meyer and Rentzel 2004). The significance of this material is unclear, and two options are discussed. The remains either originate from working the timber used for 
erecting the buildings, and/or they served as insulation against moisture from below (Gollnisch-Moos 1999).

The cultural deposits of L1 were for the most part a mixture of livestock bedding material (undigested), fodder, and dung of sheep/goat (Hall and Kenward 1998), and this is subsequently called (stable) manure. The high ratio of chaff to grains/seeds supports this interpretation. In fact, dung remains of sheep/goat that included undigested chaff/ testa remains and seeds/fruits of wild plants were found together with fly pupae and other remains that can be interpreted as bedding material and/or as fodder. The distinction between bedding and fodder is not always easy (Kühn and Wick 2010). Among all the types of material, the fragmented cereal testa found in the samples as well as in dung remains, together with seeds of Camelina sativa may hint at the presence of (undigested) animal fodder. The $C$. sativa seeds have a high nutritional value because of their oil content, and chaff of $C$. sativa was used for animal fodder in historical times (Körber-Grohne 1994). Wood chips, bark and probably also the remains of leaves and fronds were most probably part of the bedding, possibly also chaff and threshing remains of $C$. sativa.

Of special interest are the meadow plants, which, in general, could have been introduced by the animals themselves after grazing outside the settlement, or brought in as hay by the humans. Since in L1 they include very well preserved flower heads of Centaurea scabiosa, other Asteraceae, Trifolium sp. calyces (in part with fruits inside) and flowers, there is no evidence for their passage through the stomach and intestine of ruminants. Thus the meadow plants hint at the use of hay. Although humans brought the fodder/bedding into L1, I argue that sheep/goats also grazed outside the site, as indicated by various diaspores of berries, acorns and hazelnuts in the dung and manure, a scenario supported by the palynological analysis of the dung (Heitz-Weniger 2014).

The presence of droppings of sheep/goat is very common in prehistoric lakeside settlements in Poland (e.g. Mołtajny) to the northern circum-alpine region (e.g. Kühn et al. 2013; Polcyn 1995; Pydyn and Gackowski 2011; Rasmussen 1993). However, the percentages of faeces and manure in cultural layers are difficult to estimate, for if the preservation is bad, the droppings are (almost) dissolved, and other special identification criteria including insect remains (Hall and Kenward 1998) were not considered and coprophilous spores were not investigated. Apart from the stable manure, the cultural deposits included in small quantities sweepings/dirt from the houses/herds and rubbish, represented by archaeological finds (Pranckènaite 2012), and on-site vegetation. We are clearly just at the beginning of the process of understanding the circumstances and the kind of deposition of organic material in cultural layers at lakeside settlements (Haas et al. 2007).
Wild and cultivated plants

The spectrum of wild plants found in L1 is comparable to those from other Central European lakeside settlements, even those of other regions and periods, for example in Poland or the northern Alpine foreland (e.g. Brombacher and Jacomet 1997; Maier 2001; Jacomet 2008; Kroll 2010), and is composed of plants from woodlands, woodland edges, meadows, ruderal sites and riverine vegetation, while water plants represent the local vegetation. Since riverine and water plants (e.g. Filipendula ulmaria and Trapa natans) occur in a restricted number and are mechanically destroyed, it can be assumed that either they were eaten by animals and got into the deposits with the dung or, as water plants are concentrated mainly in the middle part of the profiles, they might indicate a flooding event. For lack of evidence the origin of these plants remains unclear. However, extensive and/or frequent flooding during the whole occupation period can be excluded, as archaeobotanical and also palynological and micromorphological analyses show (Ismail-Meyer 2014; Heitz-Weniger 2014).

Remains of wild fruits such as Corylus avellana, Fragaria sp., Rubus idaeus and Malus sp. (apples) have been found in many prehistoric sites in northern Central Europe, and they are usually interpreted as wild fruits which were collected for human consumption (Wasylikowa et al. 1991; Antanaitis-Jacobs et al. 2004). In L1, even a broken pot with collected hazelnuts is part of the archaeological record (Baubonis et al. 2006). Nevertheless, except hazelnuts, which clearly were collected, all other wild edible plants most probably might have been eaten by the animals and then ended up as dung in the cultural deposits of L1.

The crops of L1, the cereals Triticum spelta, T. dicoccon, Hordeum vulgare, Panicum miliaceum and the legume Pisum sativum, were common in a large geographical area in the LBA and IA throughout the whole of Central Europe including the Baltic (e.g. Wasylikowa et al. 1991; Jacomet et al 1998, 1999; Schmidl et al. 2007; Kreuz and Schäfer 2008; Grabowski 2011; Stika and Heiss 2012).

The only oil plant found so far in L1 is Camelina sativa. This is interesting, since differences in the use of either $C$. sativa or Linum usitatissimum can be observed within the geographical area considered here. C. sativa is present in the archaeobotanical record from the Neolithic onwards in southern Central Europe (Zohary et al. 2012), but due to its restricted number and mixture with Linum seeds, it is interpreted as weed (Jacomet et al. 1989; Larsson 2013). In southern/middle Central Europe the first evidence for the use of $C$. sativa as an oil plant comes from the LBA, with increasing importance in the Roman IA (Jacquat 1988, 1989; Kreuz 2004; Stika and Heiss 2012). A similar temporal pattern is observed in northern Germany, Poland and 
southern Scandinavia. From the LBA onwards, $C$. sativa is present more frequently and was additionally found in assemblages of charred seeds and in vessels, which indicates its cultivation and consumption (Tomczyńska and Wasylikowa 1988; Körber Grohne 1994; Latałowa and Pińska 2010; Grabowski 2011; Karg 2012; Stika and Heiss 2012; Larsson 2013). For Latvia, the archaeobotanical evidence is dated back to about 2,000 years ago (Rasinš and Taurina 1983; Sillasoo et al. 2009).

A different pattern is observed for Linum usitatissimum, which has been cultivated in the southern/middle part of Central Europe from the time of the Linearbandkeramik Culture in the 6th millennium cal. BC onwards and which appears frequently and with high ubiquity in Neolithic and Bronze Age lake settlements in the northern Alpine foreland (Buurman and Pals 1974; Jacomet 2007; KohlerSchneider 2007; Kreuz 2007; Karg 2012). In Poland and northern Germany, Linum also occurs from the Neolithic onwards. Interestingly in Poland in some BA sites like Bruszczewo II, Linum is absent, despite excellent (waterlogged) preservation conditions and detailed archaeobotanical investigation; in Denmark Linum occurs for the first time in the EBA (1800-1100 cal. BC) (Wasylikowa et al. 1991; Runge and Henriksen 2007; Kroll 2010; Stika and Heiss 2012). The introduction of L. usitatissimum into southern Scandinavia is dated to the LBA (Grabowski 2011; Karg 2012; Larsson 2013). At least from the Roman IA onwards it was used there for textile production (Grabowski 2011; Karg 2012; Larsson 2013). Henriksen (2009) suggests that L. usitatissimum was introduced to Scandinavia slightly later than Camelina sativa. For the eastern Baltic the earliest evidence comes from Estonia and is dated much later, to the 6th century cal. AD (Moora 1957; Kriiska et al. 2005). The earliest evidence of L. usitatissimum was found in Lithuania even later, in historical times in the 13th/15th century cal. AD (Stančikaite et al. 2008) and by pollen dated to the 15th/17th century (Kondratiene 1998). This is remakable, because Linum could have grown in Lithuania in the LBA-EIA as climatic data show (Gaigalas 2004; Damušyte 2011). The region of Moletai including Lake Luokesa was especially famous in more recent historical times for flax cultivation and textile manufacture (http://muziejus.moletai.lt). It appears that Linum was used in the eastern Baltic, including Lithuania, much later than in the western and southern part of northern Central Europe. So, if the occurrence of $C$. sativa in the LBA-EIA and the much later introduction of $L$. usitatissimum in the eastern Baltic is not caused by a bias due to the state of research, it might be related to cultural preferences and in particular to the different uses. While Linum could have been used as an oil and/or as a fibre plant, the use of $C$. sativa was restricted to the oil-rich seeds and/or the use of the stems as animal fodder or insulation (Körber-Grohne 1994; Larsson 2013). It seems that L1, also from an archaeobotanical point of view, belongs to the cultural context of eastern Baltic LBA-EIA cultures, where $C$. sativa was introduced before Linum.

\section{Subsistence economy and palaeoenvironment}

Despite the limited size of the investigated area, some suggestions about subsistence economy and palaeoenvironment can be made. Important questions of subsistence economy concern the methods of arable farming (winter/ summer crops), the processing and storage of crops, what kind of food supply was used (arable farming, livestock husbandry, fishing, hunting, gathering) and the question whether the settlement was a producer or a consumer site.

In L1 both weeds of ruderal habitats or summer cereal/ root crops (e.g. Chenopodium album) and typical weeds of winter cereals (e.g. Fallopia convolvulus) have been identified. Nevertheless, it is impossible to infer which cereal was cultivated as a winter or summer crop, because the weeds are not associated with a single crop in the layer, as would be the case in storage finds. However, the results from L1 indicate that arable farming, hay-making and grassland management were part of the agricultural activities as well as animal husbandry with pasture, which corresponds to the general assumption of the opening of the landscape of the Baltic in the LBA-EIA as observed in pollen studies (Antanaitis-Jacobs and Stančikaite 2004; Lang 2007; Wacnik 2009; Haas and Wahlmüller 2010). Pollen data from L1 let us conclude that agriculture intensified during the transitional period from the LBA to the EIA but had started before the settlement was established (Heitz-Weniger 2014). Considering the fact that a settlement like L1 with its intricate structure and subsistence economy cannot emerge ex nihilo and the climatic change with warmer temperature and decrease of water levels had started already about 750 cal. BC (Gaigalas 2004; Sillasoo et al. 2009), it is likely that there were other settlements nearby Lake Luokesa before L1. Due to the different soils in the surroundings and the results from the more eastern Labanoras region (Soil Atlas of Europe 2005; Gadamavičius et al. 2011), which show just marginal human impact, it seems more probable that earlier and contemporary agricultural activities can be expected in the west.

The issue of the definition of a producer and consumer site is still discussed in archaeobotany (e.g. Smith 2001; Van der Veen and Jones 2006). As for L1, taking together all available sources of information, it can be argued that besides arable farming (including fruits/seeds and chaff), the livestock husbandry of sheep/goats could be proven by dung. Fishing and hunting (Pranckenaitè 2012, 2014) and the collection of fruits/plants like hazelnuts (Baubonis et al. 
2006) were also part of the subsistence of the inhabitants of L1. Finds of grinding stones, fire-places and a few carbonised cereal grains together support the evidence of food preparation at the site. The economy of L1 was not that of a pure consumer site, but it remains unclear if a surplus was produced or not. The spectrum of activities and the plant taxa spectrum suggest both, producing and consuming, similar to lakeside settlements of other periods and regions (e.g. Jacomet et al. 2004; Jacomet 2007).

The settlers of L1 probably had a noticeable impact on the nearby environment; since flocks grazed in the woods and surroundings of the settlement, fern was brought into the settlement from the woods, wood was cut, and meadows for hay-making and arable fields must have been close by. This assumption is supported by palynological data that show a great impact of human influenced habitats and the analyses of four dung remains confirm that the animals had eaten various plants probably outside L1 (Heitz-Weniger 2014).

L1 belongs to the Brushed Pottery Culture or its local variant (Pranckenaite 2012, 2014) and the archaeobotany results in this paper and pollen data (Heitz-Weniger 2014) are in agreement with other results from northern Central Europe (Henriksen 2009; Grabowski 2011; Karg 2012; Larsson 2013), while differences to southern Central Europe can be observed in the choice of oil plants. In contrast, the use of habitats in the surroundings of L1 and the composition of the cultural deposits of L1 are comparable to the rest of the Baltic region as well as to the lakeshore settlements in the northern Alpine foreland, with high dynamics in settlement strategies (e.g. Bleicher 2009; Ebersbach 2010a, b, 2013), even if the archaeologically defined cultures of the settlements were different. This indicates that the form of subsistence, use of the environment and the site formation processes were similar over a large part of Europe, but that local or regional habits influenced the choice of crops, even if the climate would have allowed other preferences, such as the cultivation of Linum instead of Camelina in Luokesa 1. This shows once more that the so called "lake-dwelling phenomenon" was not an expression of an autonomous culture, and lakeshore settlements occurred diachronically in different archaeological cultures, but were related to the archaeological cultures in the same regions (Pranckènaite 2012; Ebersbach 2013).

The end of the lakeside settlement L1

It remains unclear what exactly was the reason for the abandonment of L1. However, traces of fire in the archaeologically investigated area (Pranckènaitè 2012) and layers of (partially) carbonised organic material on top of the cultural deposits suggest that there was a fire. Maybe that was the reason for the abandonment, but to be sure, further analyses would have to be carried out to investigate the extent of the fire. Traces of decay on wood and of other organic remains indicate that the site was then exposed to air and it rotted before it was covered with water again (Pollmann, accepted). The aquatic plants in the sandy sediment layer above the cultural deposits including Characeae, Najas marina, N. intermedia, Nuphar lutea, or lakeshore zone vegetation such as Schoenoplectus lacustris, represent the environments after the end of L1, when it was flooded again. The plants indicate that the water was more eutrophic than before the occupation period. This could have been directly caused by the presence of the settlement and therefore by pollution of the water with more nitrate/phosphate and other nutrients (Wegmüller 1976; Jacomet 1985; Rösch 1985; Brombacher and Jacomet 1997; Haas and Wahlmüller 2010). Future evaluation of the complete dataset from L1 will allow a deeper insight into site formation, taphonomy, human impact on the environment, animal husbandry and the construction of the buildings of this fascinating lake shore settlement.

\section{Conclusions}

Archaeobotanical analyses at L1 contribute to the archaeobotanical research data set in Lithuania and to the general understanding of the functioning of lakeshore settlements in Europe. Currently, L1 is the archaeobotanically best investigated site of the LBA-EIA in Lithuania.

After the last Ice Age, lake marl accumulated on the submerged site of L1 in oligo- to mesotrophic conditions. The morainic shoal was exposed when L1 was constructed. The occupation period of L1 is represented in the profiles by a thick cultural deposit, which to a major part consisted of manure, to a minor part of dirt/sweepings, rubbish and remains of on-site vegetation. Small ruminants were kept within the settlement and fed with hay, oil-rich seeds/cereal grains/chaff and they also grazed outside the settlement as the spectrum of plants from the surrounding habitats on dry land shows. The spectrum of crops indicates the cultivation of cereals, pulses and the oil plant Camelina sativa near L1, as at other sites in northern Central Europe. The spectrum of activities and plants suggests production and consumption, similar to other lakeside settlements, but it remains unclear whether a surplus was produced or not.

C. sativa was found for the first time in prehistoric Lithuania and it can be clearly interpreted as a crop as early as the LBA-EIA. Because remains of stable manure dominated in the samples and no crop storage was found within the excavated area, more detailed insights into the modes and techniques of crop cultivation and processing await further investigations in order to evaluate spatial 
analysis and intra-site pattern. Aquatic plants indicate a change to a more eutrophic state from the occupation period of L1 onwards.

The reason for the settlement's end remains unclear, but charred and partially charred plant remains, wooden structures and archaeological artefacts (Pranckènaite 2012) indicate that a there had been a fire, destroying at least a part of L1 at the end of the occupation time. The central (archaeologically investigated) part of L1 was not rebuilt, but decay started before the site was flooded by the lake water and reed established on the site.

Acknowledgements My thanks go to Elena Pranckenaite, head of the excavation on Lake Luokesa who supported me also with the translation of Lithuanian articles, and my colleagues at Integrative Prehistory and Archaeological Science (IPAS), who helped me with the identification of macroremains and were open for many fruitful discussions, especially Örni Akeret, Patricia Vandorpe and Petra Zibulski. For help during writing I thank my colleague Angela Schlumbaum (IPAS) and two anonymous reviewers who largely improved the manuscript. Many thanks go also to Stefanie Jacomet, who supervised my doctorate work which was financed by the Swiss National Science Foundation (Project-No. K-13K1-117893/1) and by the Fritz Sarasin Stiftung.

\section{References}

Antanaitis-Jacobs I, Kisielienė D, Stančikaitė M (2002) Macrobotanical and palynological research at two archaeological sites in Lithuania. In: Viklund K (ed) Nordic archaeobotany - NAG 2000 in Umea, vol 15., Archaeology and environmentVMC KBC Umea Universitet, Umea, pp 5-21

Antanaitis-Jacobs I, Kisielienè D, Stančikaitė M (2004) Archeobotanika Lietuvoje: Makrobotaniniai ir palinoliginiai Tyrinejjimai. Lietuvos Archeologija 26:77-98

Antanaitis-Jacobs I, Stančikaite M (2004) The impact of the economic acitivities of Stone and Bronze Age populations on their environment according to the archaeobotanical evidence. Lietuvos Archeologija 25:251-266

Baubonis Z, Kraniauskas R, Kvedaravičius M (2001) Luokesų ežero gyvenvietes povandeniniai archeologiniai tyrinejimai. Archeologiniai tyrinejimai Lietuvoje 2000 metais:228-231

Baubonis Z, Motuzaite G, Pranckenaite E (2002) Luokesụ ežero (Molètụ r.) senovès gyvenviečiu 2 ir 3 povandeniniai archeologinia-ižvalgymai. Archeologiniai tyrinejimai Lietuvoje 2001 metais:268-270

Baubonis Z, Kvedaravičius M, Motuzaite G, Pranckènaite E (2006) Luokesų ežero polinès gyvenvietès I ir II. Archeologiniai tyrinejimai Lietuvoje 2004 metais:315-316

Birks HH (2007) Plant macrofossil introduction. In: Elias S (ed) Encyclopedia of Quaternary science. Elsevier, Amsterdam, pp 2,266-2,288

Bleicher N (2009) Altes Holz in neuem Licht. Archäologische und dendrochronologische Untersuchungen an spätneolithischen Feuchtbodensiedlungen in Oberschwaben. (Berichte $\mathrm{zu}$ den Ufer- und Moorsiedlungen Südwestdeutschlands V, Materialhefte Archäol Bad-Württ 83) Theiss, Stuttgart

Bleicher, N (2014) Dendrochronological analyses of wood samples from a Late Bronze to early Iron Age site at Lake Luokesa, Lithuania. Veget Hist Archaeobot 23 (this volume)
Bogucki P (2013) People, lakes and forest in the Baltic region: a prehistoric perspective. In: O'Sullivan A, Menotti F (eds) The Oxford handbook of wetland archaeology. Oxfords handbooks in archaeology. Oxford University Press, Oxford, pp 811-826

Brazaitis D (2005) Ankstyvasis metalụ laikotarpis. In: Girininkas A (ed) Lietuvos istorija. Akmens amžius, Baltos lankos, Vilnius, pp 251-317

Brombacher C, Jacomet S (1997) Ackerbau, Sammelwirtschaft und Umwelt: Ergebnisse archäobotanischer Untersuchungen. In: Schibler J, Hüster-Plogmann $\mathrm{H}$, Jacomet $\mathrm{S}$, Brombacher $\mathrm{C}$, Gross-Klee E, Rast-Eicher A (eds) Ökonomie und Ökologie neolithischer und bronzezeitlicher Ufersiedlungen am Zürichsee. Ergebnisse der Ausgrabungen Mozartstrasse, Kanalisationssanierungen Seefeld, AKAD/Pressehaus und Mythenschloss in Zürich. (Monographien der Kantonsarchäologie Zürich 20) Egg, Zürich, pp 220-279

Bullock P, Fedoroff N, Jongerius A, Stoops G, Tursina T, Babel U (1985) Handbook for soil thin section description. Waine Research Publication, Wolverhampton

Buurman J, Pals JP (1974) Some remarks on prehistoric flax in the Netherlands. (I.P.P. publications 196) ROB, Amersfoort

Cappers R, Bekker RM, Jans JEA (2006) Digitale Zadenatlas van Nederland (Digital seed atlas of the Netherlands). (Groningen Archaeological Studies 4) Barkhuis Publishing and Groningen University Library, Groningen

Damušyte A (2011) Post-glacial geological history of the Lithuanian coastal area (summary of doctoral thesis). Vilnus University, Vilnius

Daugnora L, Girininkas A, Guobyte R, Kisieliene D, Simniškyte A, Stančikaite M (2004) Juodonys ir jaros apyežeris: gamta ir gyventojai. Lietuvos archeologija 26:111-134

Dixon N (2004) The crannogs of Scotland: an underwater archaeology. Tempus, Stroud

Ebersbach R (2010a) Soziale Einheiten zwischen "Haus" und "Dorf" - neue Erkenntnisse aus den Seeufersiedlungen. In: Claßen E, Doppler T, Ramminger B (eds) Familie - Verwandtschaft Sozialstrukturen: Sozialarchäologische Forschungen zu neolithischen Befunden. Fokus Jungsteinzeit: Berichte der AG Neolithikum 1. Welt und Erde, Kerpen-Loogh, pp 141-156

Ebersbach R (2010b) Vom Entstehen und Vergehen - Überlegungen zur Dynamik von Feuchtbodenhäusern und -siedlungen. In: Matuschik I, Strahm C, Eberschweiler B et al (eds) Vernetzungen - Aspekte siedlungsarchäologischer Forschung. Lavori, Freiburg, pp 41-50

Ebersbach R (2013) Houses, households and settlements: architecture and living spaces. In: Menotti F, O'Sullivan A (eds) The Oxford handbook of wetland archaeology. Oxford University Press, London, pp 283-301

Ellenberg H (1991) Zeigerwerte von Pflanzen in Mitteleuropa, 3rd edn. (Scripta Geobotanica 18) Goltze, Göttingen

Gadamavičius A, Stančikaitè M, Kisielienè D, Mažeika J, Gryguc G (2011) Post-glacial vegetation and environment of the Labanoras Region, East Lithuania: implications for regional history. Geol Quarterly 55:269-284

Gaigalas A (2004) Environmental study of the Bronze-Iron Age transition period of eastern Europe. In: Scott EM, Alekseev AY, Zaitseva G (eds) Impact of the environment on human migration in Eurasia: Proceedings of the NATO Advanced Research Workshop, St. Petersburg, 15-18 November 2003. Kluwer, Dordrecht, pp 243-254

Girininkas A (2008) The influence of the environment on the human population around lake Kretuonas during the Stone Age and the Bronze Age. Archaeologia Baltica 9:15-32

Gollnisch-Moos H (1999) Ürschhausen-Horn. Haus- und Siedlungsstrukturen der spätestbronzezeitlichen Siedlung. (Archäologie im Thurgau 7) Departement für Erziehung und Kultur des Kantons Thurgau, Frauenfeld 
Grabowski R (2011) Changes in cereal cultivation during the Iron Age in southern Sweden: a compilation and interpretation of the archaeobotanical material. Veget Hist Archaeobot 20:479-494

Guobytė M, Satkūnas J (2011) Pleistocene glaciations in Lithuania. Developments in Quarternary Science 15:231-246

Haas JN, Karg S, Starnberger R (2007) Vegetationswandel, Klima und prähistorische Landwirtschaftssysteme im Umfeld der Pfahlbausiedlung Pfyn Breitenloo. In: Leuzinger U (ed) PfynBreitenloo - Die jungsteinzeitliche Pfahlbausiedlung. (Archäologie im Thurgau 14) Departement für Erziehung und Kultur des Kantons Thurgau, Frauenfeld, pp 111-136

Haas JN, Wahlmüller N (2010) Floren-, Vegetations- und Milieuveränderungen im Zuge der bronzezeitlichen Besiedlung von Bruszczewo (Polen) und der landwirtschaftlichen Nutzung der umliegenden Gebiete. In: Müller J, Czebreszuk J, Kneisel J (eds) Bruszczewo II - Ausgrabungen und Forschungen in einer prähistorischen Siedlungskammer Großpolens. Studien zur Archäologie in Ostmitteleuropa 6:50-81

Hall A, Kenward H (1998) Disentangling dung: pathways to stable manure. Environ Archaeol 1:123-126

Harding A, Ostoja-Zagórski J, Palmer C, Rackham J (2004) Sobiejuchy: A fortified site of the early Iron Age in Poland. Institute of Archaeology and Ethnology, Polish Academy of Science, Warsaw

Heitz-Weniger, A (2014) Palynological investigations at the Late Bronze-Early Iron Age lakeshore settlement of Luokesa 1 (Moletai District, Lithuania): a contribution to the Middle-Late Holocene vegetation history of the south-eastern Baltic regions. Veget Hist Archaeobot 23 (this volume). doi10.1007/s00334014-0456-0

Henderson JC (1998) Islets through time: the definition, dating and distribution of Scottish crannogs. J Archaeol 17:227-244

Henriksen PS (2009) Archaeobotanical evidence of flax in the prehistoric Denmark. In: Karg S (ed) The International Flax Network. Communicating Culture Aps, Copenhagen, pp 22-23

Hosch S, Zibulski P (2003) The influence of inconsistent wet-sieving procedures on the macroremains concentration in waterlogged sediments. J Archaeol Sci 30:849-857

Ismail-Meyer, K (2014) The potential of micromorphology for interpreting sedimentation processes in wetland sites: a case study of a Late Bronze-early Iron Age lakeshore settlement at Lake Luokesa (Lithuania). Veget Hist Archaeobot 23 (this volume). doi10.1007/s00334-014-0459-x

Ismail-Meyer K, Rentzel P (2004) Mikromorphologische Untersuchung der Schichtabfolge. In: Jacomet S, Leuzinger U, Schibler J (eds) Die jungsteinzeitliche Seeufersiedlung Arbon Bleiche 3. Umwelt und Wirtschaft. Archäologie im Thurgau 12. Departement für Erziehung und Kultur des Kantons Thurgau, Frauenfeld, pp 66-80

Jacomet S (1985) Botanische Makroreste aus den Sedimenten des neolithischen Siedlungsplatzes AKAD-Seehofstrasse am untersten Zürichsee. Die Reste der Uferpflanzen und ihre Aussagemöglichkeiten zu Vegetationsgeschichte, Schichtentstehung und Seespiegelschwankungen. (Zürcher Studien zur Archäologie 3) Juris, Zürich

Jacomet S (2007) Neolithic plant economies in the northern Alpine foreland from 5500 to 3500 BC cal. In: Colledge S, Conolly J (eds) The origins and spread of domestic plants in Southwest Asia and Europe. Left Coast Press, Walnut Creek, pp 221-258

Jacomet S (2008) Subsistenz und Landnutzung während des 3. Jahrtausends v. Chr. aufgrund von archäobotanischen Daten aus dem südwestlichen Mitteleuropa. In: Dörfler W, Müller J (eds) Umwelt-Wirtschaft-Siedlungen im dritten vorchristlichen Jahrtausend Mitteleuropas und Südskandinaviens. (Offa-Bücher 84) Wachholz, Neumünster, pp 355-377
Jacomet S (2013) Archaeobotany. Analyses of plant remains from waterlogged archaeological sites. In: O'Sullivan A, Menotti F (eds) The Oxford handbook of wetland archaeology. Oxford University Press, Oxford, pp 497-514

Jacomet S, Brombacher C (2005) Reconstructing intra-site patterns in Neolithic lakeshore settlements: the state of archaeobotanical research and future prospects. In: Della Casa P, Trachsel M (eds) WES'04-Wetland economies and societies. (Collectio Archaeologica 3) Chronos, Zürich, pp 69-94

Jacomet S, Brombacher C, Dick M (1989) Archäobotanik am Zürichsee. Ackerbau, Sammelwirtschaft und Umwelt von neolitischen und bronzezeitlichen Seeufersiedlungen im Raum Zürich. Ergebnisse von Untersuchungen pflanzlicher Makroreste der Jahre 1979-1988. (Ber Zürcher Denkmalpfl Monogr 3) Orel Füssli, Zürich

Jacomet S, Rachoud-Schneider AM, Zoller H, Burga CA (1998) Vegetationsentwicklung, Vegetationsveränderung durch menschlichen Einfluss, Ackerbau und Sammelwirtschaft. In: Hochuli S, Niffeler U, Rychner V (eds) (Die Schweiz vom Paläolithikum bis zum frühen Mittelalter (SPM) 3: Bronzezeit) Basel, pp 141-170

Jacomet S, Jacquat C, Winter M, Wick L (1999) Umwelt, Ackerbau und Sammelwirtschaft. In: Müller F, Kaenel G, Lüscher G (eds) (Die Schweiz vom Paläolithikum bis zum frühen Mittelalter (SPM) 4: Eisenzeit) Schweizerische Gesellschaft für Ur- und Frühgeschichte, Basel, pp 98-115

Jacomet S, Leuzinger U, Schibler J (2004) Die jungsteinzeitliche Seeufersiedlung Arbon Bleiche 3. Umwelt und Wirtschaft. (Archäologie im Thurgau 12) Departement für Erziehung und Kultur des Kantons Thurgau, Frauenfeld

Jacquat C (1988) Hauterive-Champréveyre 1 Les plantes de l'âge du Bronze. Catalogue des fruits et des graines. (Archéologie neuchâteloise 7) Du Ruau, Saint-Blaise

Jacquat C (1989) Hauterive-Champréveyre 2 Les plantes de l'âge du Bronze. Contribution à l'histoire de l'environnement et de l'alimentation. (Archéologie Neuchâteloise 8) Du Ruau, SaintBlaise

Jones M (1991) Sampling in palaeoethnobotany. In: Van Zeist WA, Wasylikowa K, Behre K-E (eds) Progress in Old World palaeoethnobotany. Balkema, Rotterdam, pp 53-62

Kabailienè M (2006) Gamtinès aplikos raida Lietuvoje per 14000 metụ. Vilniaus universiteto leidykla, Vilnius

Karg S (2012) Oil-rich seeds from prehistoric contexts in southern Scanidinavia - reflections on the archaeobotanical records of flax, hemp, gold of pleasure, and corn spurrey. Acta Palaeobot 52:17-24

Kenward HK, Hall AR, Jones AKC (1980) A tested set of techniques for the extraction of plant and animal macrofossils from waterlogged archaeological deposits. Sci Archaeol 22:3-15

Kimmig W (1992) Die Wasserburg Buchau, eine spätbronzezeitliche Siedlung: Forschungsgeschichte und Kleinfunde. (Materialh Vor- Frühgesch Bad-Württ 16) Theiss, Stuttgart

Kisielienė D, Masiulienė I, Daugnora L, Stančikaitė M, Mažeika J, Vaikutiene G, R P (2012) History of the environment and population of the old town of Klaipeda, Western Lithuania: Multidisciplinary approach to the Last Millennium. Radiocarbon $54: 1,003-1,015$

Kohler-Schneider M (2007) Early agriculture and subsistence in Austria: a review of Neolithic plant records. In: Colledge S, Conolly $\mathbf{J}$ (eds) The origins and spread of domestic plants in southwest Asia and Europe. Left Coast Press, Walnut Creek, pp 209-220

Kondratienè O (1998) Palynological evidence for the development of agriculture in Lithuania. Pact 54:61-67

Körber-Grohne U (1994) Nutzpflanzen in Deutschland. Kulturgeschichte und Biologie, Theiss, Stuttgart 
Kreuz A (2004) Landwirtschaft im Umbruch? Archäobotanische Untersuchungen zu den Jahrhunderten um Christi Geburt in Hessen und Mainfranken. Ber RGK 85:97-292

Kreuz A (2007) Archaeobotanical perspectives on the beginning of agriculture north of the Alps. In: Colledge S, Conolly J (eds) The origins and spread of domestic plants in southwest Asia and Europe. Left Coast Press, Walnut Creek, pp 259-294

Kreuz A, Schäfer E (2008) Archaeobotanical consideration of the development of Pre-Roman Iron Age crop growing in the region of Hesse, Germany, and the question of agricultural production and consumption at hillfort sites and open settlements. Veget Hist Archaeobot 17:159-181

Kriiska A, Roio M (2011) Prehistoric archaeology of wetlands in Estonia. In: Pranckenaite E (ed) Wetland settlements in the Baltic region. Vilnius, pp 55-73

Kriiska A, Lavento M, Peets J (2005) New AMS Dates of the Neolithic and Bronze Age ceramics in Estonia: preliminary results and interpretations. Estonian J Archaeol 9:3-31

Kroll H (2010) Die Archäobotanik von Bruszczewo - Darstellung und Interpretation wichtiger Ergebnisse. In: Müller J, Czebreszuk J, Kneisel J (eds) Bruszczewo II. Studien zur Archäologie in Ostmitteleuropa 6:250-287

Kühn M, Wick L (2010) Pflanzenreste in Koprolithen von Schafen und Ziegen: Was frassen die kleinen Wiederkäuer von PfäffikonBurg? In: Eberli U (ed) Die horgenzeitliche Siedlung von Pfäffikon-Burg. (Monographien der Kantonsarchäologie Zürich 40) Baudirektion Kanton Zürich, Zürich und Elgg, pp 256-261

Kühn M, Maier U, Herbig C, Isamil-Meyer K, Le Bailly M, Wick L (2013) Methods for the examination of cattle, sheep and goat dung in prehistoric wetland settlements with examples of the sites Alleshausen-Täschenwiesen and Alleshausen-Grundwiesen (around cal 2900 BC) Lake Federsee, south-west Germany. J Environ Archaeol 18:43-57

Kunskas R (ed) (2005) Development of lake and bog ecosystems The little palaeogeographical and palaeosynecological atlas. Ciklonas, Vilnius

Lang V (2007) The Bronze and Early Iron Ages in Estonia. (Estonian Archaeology 3) Tartu University Press, Tartu

Latałowa M, Pińska K (2010) Zawartość botaniczna dwóch naczyń z pozostałości osady ludności łużyckich pól popielnicowych w Polanowie na Pojezierzu Gnieźnieńskim. In: Pydyn A (ed) Archeologia Jeziora Powidzkiego. Torun, pp 197-226

Larsson M (2013) Cultivation and processing of Linum usitatissimum and Camelina sativa in southern Scandinavia during the Roman Iron Age. Veget Hist Archaeobot 22:509-520

Lauber K, Wagner G, Gygax A (2012) Flora Helvetica, 5th edn. Haupt, Bern

Lauer W, Frankenberg P (1988) Klimaklassifikation der Erde. (Geographische Rundschau 40) Westermann, Braunschweig

Lewis H (2007) Pile dwellings, changing lake conditions and sediment deposition: Preliminary soil micromorphology study of cultural deposits from underwater sites at Lake Luokesas, Moletai Region, Lithuania. J Wetland Archaeol 7:33-50

Loze I (2011) Wetlands and Stone Age wetland settlements in Latvia. In: Pranckenaite E (ed) Wetland settlements in the Baltic region. Vilnius, pp 75-91

Maier U (2001) Archäobotanische Untersuchungen in der neolithischen Ufersiedlung Hornstaad-Hörnle IA am Bodensee. In: Maier U, Vogt R (eds) Siedlungsarchäologie im Alpenvorland VI. Botanische und pedologische Untersuchungen zur Ufersiedlung Hornstaad-Hörnle IA. (Siedlungsarchäologie im Alpenvorland 6) Forsch Ber Vor- Frühgesch Bad-Württ 74. Theiss, Stuttgart, pp 9-384

Maier U (2004) Archäobotanische Untersuchungen in jung- und endneolithischen Moorsiedlungen am Federsee. In: Köninger J, Schlichtherle H (eds) Ökonomischer und ökologischer Wandel am vorgeschichtlichen Federsee. Archäologische und naturwissenschaftliche Untersuchungen. (Hemmenhofener Skripte 5) Landesdenkmalamt Baden-Württemberg, Gaienhofen-Hemmenhofen, pp 71-159

Maier U, Harwath A (2011) Detecting intra-site patterns with systematic sampling strategies. Archaeobotanical grid sampling of the lakeshore settlement Bad Buchau-Torwiesen II, southwest Germany. Veget Hist Archaeobot 20:349-365

Masiuliene I (2009) 16th-17th cen. Klaipeda town resident's lifestyle (by archaeological, paleobotanical and zooarchaeological data of Kurpiu street plots). Archaeologia Baltica 12:95-111

Menotti F (ed) (2004) Living on the lake in prehistoric Europe - 150 years of lake-dwelling research. Routledge, London

Menotti F (2012) Wetland archaeology and beyond: Theory and practice. Oxford University Press, Oxford

Menotti F, O'Sullivan A (eds) (2013) The Oxford handbook of wetland archaeology. Oxford handbooks in archaeology. Oxford University Press, Oxford

Menotti F, Baubonis Z, Brazaitis D, Higham T, Kvedaravičius M, Lewis H, Motuzaite G, Pranckenaite E (2005) The first lakedwellers of Lithuania: Late Bronze Age pile settlements on Lake Luokesas. Oxford J Archaeol 24:381-403

Merkevičius A, Nemickienè R (2011) Senieji laukai Šiaurès Vakarụ Lietuvoje. Vilnius

Moora H (1957) Varasemaid andmeid ketramisest je kudumisest. Eesti rahvaroivad XIX sajandist ja XX sajandi algult, Tallin, pp 2(003-2):009

Motuzaite Matuzevičiūte G (2007) Living on the lake and farming the land. Archaeobotanical investigation on Luokesai I lake dwelling site. Lietuvos Archeologija 31:123-138

Motuzaite Matuzevičiūte G (2008) Living above the water or on dry land? The application of soil analysis methods to investigate a submerged Bronze Age to Early Iron Age lake dwelling site in eastern Lithuania. In: Girininkas A (ed) (Archaeologia Baltica 9) Klaipeda University Press, Klaipeda, pp 33-46

Polcyn M (1995) Pszenica orkisz (Triticum spelta) i jęczmień zwyczajny (Hordeum vulgare) z osady nawodnej ludności kultury kurhanów zachodniobałtyjskich w Mołtajnach woj. olsztyńskie (Stan. 1) [Spelt (Triticum spelta) and barley (Hordeum vulgare) from the lake settlement of the West Baltian Barrow Culture in Mołtajny, Olsztyn Voivodeship (Site 1), in Polish]. Acta Universitatis Nicolai Copernici Archeologia 24:53-71

Pollmann B (accepted) Geschichte einer Feuchbodensiedlung um 600 v. Chr. am See Luokesa (Litauen): Rekonstruktion von Schichtgenese, Umwelt und Ernährung anhand archäobotanischer Analysen und taphonomischer Untersuchungen biologischer Makroreste. Doctoral thesis, University of Basel, Basel

Poska A, Saarse L, Veski S, Kihno K (1999) Farming from the Neolithic to the Pre-Roman Iron Age in Estonia, as reflected in pollen diagrams. Pact 57:305-317

Pranckenaite E (ed) (2011) Wetland settlements of the Baltic - A prehistoric perspective. Standartu Spaustuvè, Vilnius

Pranckènaitė E (2012) Ežerụ gyvenvietès pietryčiụ Baltijos regione ansktyvuoju metalu laikotarpiu (Lake dwellings in the SouthEastern Baltic Sea Region during The Early Metal Period). Doctoral thesis, Klaipeda University, Klaipeda

Pranckenaite E (2014) Living in wetlands in the southeastern Baltic region during the Late Bronze to early Iron Age: the archaeological context of the Luokesa lake settlements. Veget Hist Archaeobot 23 (this volume)

Pydyn A, Gackowski J (2011) Wetland archaeology of the Late Bronze Age and the Early Iron Age settlements from Poland. In: Pranckenaite E (ed) Wetland settlements in the Baltic region. Vilnius, pp 113-149

Rasinš̌ A, Taurina M (1983) Übersicht über den Artenbestand der Kulturpflanzen und Unkräuter aus archäologischen 
Ausgrabungen in der Lettischen SSR. In: Medieval castles and towns in Latvian territory. (Archaeology and Ethnography 14) Zinātne, Riga, pp 152-176 (in Latvian with German summary).

Rasmussen P (1993) Analysis of goat/sheep faeces from Egolzwil 3, Switzerland: Evidence for branch and twig foddering of livestock in the Neolithic. J Archaeol Sci 20:479-502

Rimantienè R (2005) Die Steinzeitfischer an der Ostseelagune in Litauen. Litauisches Nationalmuseum, Vilnius

Rösch M (1985) Die Pflanzenreste der neolithischen Ufersiedlung von Hornstaad-Hörnle I am westlichen Bodensee. (Berichte zu Uferund Moorsiedlungen Südwestdeutschlands 2, Materialhefte VorFrühgesch Bad-Württ 7) Theiss, Stuttgart, pp 167-199

Runge M, Henriksen PS (2007) Danmarks ældstehørindustrie. Fynske Minder 2007:145-165

Schmidl A, Jacomet S, Oeggl K (2007) Distribution patterns of cultivated plants in the Eastern Alps (Central Europe) during Iron Age. J Archaeol Sci 34:243-254

Sillasoo Ü, Poska A, Seppä H, Blaauw M, Frank M, Chambers FM (2009) Linking past cultural developments to palaeoenvironmental changes in Estonia. Veget Hist Archaeobot 18:315-327

Smith W (2001) When method meets theory: the use and misuse of cereal producer/consumer models in archaeobotany. In: Albarella U (ed) Environmental Archaeology: Meaning and Purpose. (Environmental Science and Technology Library 17. Kluwer, Dordrecht, pp 283-298

Soil Atlas of Europe (2005) European Communities, Luxembourg

Stančikaitė M, Kisielienè D, Strimaitienè A (2004) Vegetation response to the climatic and human impact changes during the Late Glacial and Holocene: case study of the marginal area of Baltija Upland, NE Lithuania. Baltica 17:17-33

Stančikaitė M, Kisielienè D, Mažeika J, Blaževičius P (2008) Environmental conditions and human interference during the 6th and 13th-15th centuries AD at Vilnius Lower Castle, east Lithuania. Veget Hist Archaeobot 17:239-250

Stančikaite M, Daugnora L, Hjelle K, Hufthammer AK (2009) The environment of the Neolithic archaeological sites in Šventoji, Western Lithuania. Quat Int 207:117-129

Stančikaitė M, Kisielienè D, Šeiriené V (2012) Paleobotanical investigations in Lithuania: Old traditions and new approach. In: Zabiela G, Baubonis Z, Marcinkevičiūtė E (eds) Archaeological investigations in independent Lithuania (1990-2010). Society of the Lithuanian Archaeology, Vilnius, pp 416-419
Stika HP, Heiss AG (2012) Bronzezeitliche Landwirtschaft in Europa - Der Versuch einer Gesamtdarstellung des Forschungsstandes. In: Willroth KH (ed) Siedlungen der älteren Bronzezeit. (Studien zur nordeuropäischen Bronzezeit 1) Wachholtz, Neumünster, pp 183-216

Tolar T, Jacomet S, Velušček A, Čufar K (2010) Recovery techniques for waterlogged archaeological sediments: a comparison of different treatment methods for samples from Neolithic lake shore settlements. Veget Hist Archaeobot 19:53-67

Tomczyńska Z, Wasylikowa K (1988) Plant material from a Hallstatt settlement at Kamieniec near Toruń, North Poland (A reinvestigation). In: Küster H (ed) Der prähistorische Mensch und seine Umwelt. (Forsch Ber Vor- Frühgesch Bad-Württ 31) Theiss, Stuttgart, pp 281-287

Tupčiauskaitė J (2012) Botanikos Mokomoji lauko praktika. Stuomeninių augalụ mokomụjụ ekskursijų konspektai, užduotys ir kontroliniai klausimai, Mokomoji knyga, Vilnius

Van der Veen M, Jones GEM (2006) A re-analysis of agricultural production and consumption: implications for understanding the British Iron Age. Veget Hist Archaeobot 15:217-228

Vandorpe P, Jacomet S (2007) Comparing different pre-treatment methods for strongly compacted organic sediments prior to wetsieving: a case study on Roman waterlogged deposits. Environ Archaeol 12:207-214

Vilkonis KK (2008) Lietuvos žaliasis rūbas Atlasas. Lutute, Kaunas Wacnik A (2009) From foraging to farming in the Great Mazurian Lake District: palynological studies on Lake Miłkowskie sediments, northeast Poland. Veget Hist Archaeobot 18:187-203

Wasylikowa K, Cârciumaru M, Hajnalová E, Hartyányi BP, Pashkevich GA, Yanushevich ZV (1991) East-Central Europe. Van Zeist W, Wasylikowa K, Behre K-E (1991) Progress in Old World palaeoethnobotany. Balkema, Rotterdam, pp 207-239

Wegmüller S (1976) Pollenanalytische Untersuchungen über die Siedlungsverhältnisse der frühneolithischen Station Egolzwil 5. In: Wyss R (ed) Das jungsteinzeitliche Jäger-Bauerndorf Egolzwil 5 im Wauwiler Moos. Archäologische Forschungen, Zürich, pp 141-162

Zohary D, Hopf M, Weiss E (2012) Domestication of plants in the Old World, 4th edn. Oxford University Press, Oxford 